\title{
ANALISIS PENGARUH STRES KERJA DALAM MEMEDIASI HUBUNGAN ANTARA POLITIK ORGANISASIONAL DENGAN PERILAKU AGRESIF (STUDI KASUS PADA RS PKU MUHAMMADIYAH DAN DKT DI YOGYAKARTA)
}

\author{
Yuni Siswanti \\ UPN "Veteran" Yogyakarta
}

\begin{abstract}
This research aim to test the impact of organizational politics to job distress and aggressive behavior, and research mediation effect job distress of relation of organizational politics and aggressive behavior. The data were collected from two hospitals, are PKU and DKT in Jogjakarta from nurses. Total respondent were 86 peoples. Regression and hierarchical regression Analysis (HRA) analyzed the data. The interesting result that organizational politics was direct effected to job distress, but wasn't direct effected to aggressive behavior. The research has succeeded establish that job distress as mediator variable in the relation of organizational politics and aggressive behavior.
\end{abstract}

Keywords: organizational behavior, job distress, aggressive behavior

PENDAHULUAN

Politik organisasional merupakan fenomena yang tidak dapat dilepaskan dalam organisasi. Setiap orang yang bekerja di organisasi/perusahaan tertentu memiliki tujuan individu tertentu, dan masing-masing punya strategi untuk meraih apa yang menjadi tujuannya tersebut. Ada yang melakukannya dengan cara bijaksana, artinya mengikuti segala peraturan organisasinya, namun ada pula yang berani melakukan beragam cara meskipun kadang menyakiti pihak lain untuk meraih kepentingannya. Semuanya tidak terlepas dari segala perilaku manusia yang memiliki berbagai keinginan. Oleh karena itu, ada sebagian orang yang memiliki pandangan bahwa segala upaya yang dilakukan dapat dipandang sebagai investasi (Cropanzano, et al., 1997) karena suatu saat akan diperoleh apa yang diinginkan seperti keuntungan ekonomi, jabatan dan status sosial (Cropanzano, Kacmar, \& Bozeman, 1995 dalam Randall, et al., 1999).

Cropanzano et al. (1997) mengidentifikasi dua konstruk yang menjelaskan karakteristik suatu social marketplace, yaitu: dukungan organisasional dan politik organisasonal. Setiap konstruk membantu menangkap karakter dari transaksi interpersonal dengan organisasi. Pada saat marketplace bersifat politik, individu-individu mencapai keinginannya dengan bersaing dan memperbesar kekuasaan sehingga investasi yang ditanamkan karyawan menjadi beresiko. Market place bersifat politik, maksudnya bila ada seseorang atau beberapa orang melakukan upaya yang bersifat 
politik untuk memenuhi kepentingan pribadinya. Upaya ini dapat berupa ingratiation behaviors (perilaku berupa hasutan) dan self promotion (mempromosikan diri sendiri) (Cook, Ferris dan Dulebohn, 1999). Menurut Valle dan Perrewe, 2000 (dalam Vigoda, 2002) politik organisasional berhubungan negatif dengan kepuasan kerja, namun berhubungan positif dengan job distress seperti burnout atau somatic tention dan intensitas turnover.

Berdasarkan studi-studi terdahulu, ditemukan bahwa politik organisasional berhubungan dengan sikap kerja, kinerja dan job distress. (Cropanzano et al., 1997; Bozeman et al., 1994; Valle \& Perrewe, 2000 dalam Vigoda, 2002).

Studi tentang kekuasaan dan pengaruhnya sangat penting untuk dipahami bagaimana organisasi melakukan aktivitasnya. Sangat memungkinkan untuk melibatkan kekuasaaan (power) dalam setiap interaksi dan hubungan sosial pada organisasi. Orang cenderung untuk mempengaruhi individu lain dan organisasi dalam setiap tindakan atau perilakunya, misalnya manajer mempengaruhi karyawan untuk tujuan meningkatkan kinerja dan keuntungan.

Dalam usahanya mempengaruhi orang lain, individu melakukan social influence, dan tindakan yang lebih terfokus lagi adalah melakukan organizational politics (politik organisasional) (Greenberg \& Baron, 2000). Perilaku politik merupakan perilaku yang secara organisasional tidak ada sanksinya, yang mungkin dapat merugikan bagi tujuan organisasi atau bagi kepentingan orang lain dalam organisasi (Harrell-Cook, Ferris \& Dulebohn, 1999 dalam Randall, et al., 1999).

Ada dua definisi tentang politik organisasional. Satu diantaranya lebih bersifat luas yaitu melihat politik organisasional sebagai sebuah proses mempengaruhi. Namun, definisi yang lain melihat politik secara sempit, yakni bahwa politik terbatas pada perilaku untuk memaksimalkan kepentingan pribadi dalam jangka pendek atau jangka panjang (Cropanzano, et al., 1997). Politik organisasional termasuk melibatkan kepentingan seseorang di atas kepentingan organisasi (Greenberg \& Baron, 2000). Evaluasi subyektif individu terhadap situasi atau perilaku yang diobservasi sebagai politik merupakan politik organisasional yang dipersepsikan (Harrel- Cook, Ferris, \& Dulebohn, 1999). Sampai sekarang, banyak studi yang berkonsentrasi tentang pengaruh politik organisasional terhadap sikap kerja (seperti kepuasan kerja dan komitmen organisasional) serta intensitas perilaku (seperti turnover, intensitas bertindak lalai).

Beberapa reaksi potensial yang lain dari politik organisasional adalah tidak terlihat tetap (Vigoda, 2002). Sebagai contoh, adanya kemungkinan bahwa politik dalam organisasi dapat menyebabkan stres yang berdampak terhadap hasil kerja (Bozeman, Perrewe, Kacmar, Hochwater, \& Brymer, 1996; Valle \& Perrewe, 2000 dalam Vigoda, 2002). Lebih jauh dinyatakan bahwa studi-studi tentang pengaruh politik organisasional tersebut belum mampu menguji tentang konsekuensi lain yang berkaitan dengan kecemasan kerja seperti burnout atau somatic tention. Kecuali untuk kerja menurut Cropanzano, et al. (1997), hanya beberapa studi yang menyelidiki dampak terhadap stres yang berhubungan dengan hasil. 
Menurut hasil studi Ferris et al. (1994), Bozeman et al. (1996), Ferris et al. (1996), Kacmar et al. (1999), Vallee dan Perrewe (2000), politik organisasional berhubungan positif dengan job distress dan kecemasan kerja. Dari hasil studi Cropanzano et al. (1997) ditemukan bahwa work stress (job tention, somatic tention, general fatigue dan burnout) berhubungan positif dengan politik organisasional. Jika persepsi karyawan terhadap lingkungan kerjanya sedang dalam suasana ada upaya berpolitik oleh pihak-pihak tertentu, maka mereka cenderung merasa berada dalam kondisi cemas dan tegang. Dalam situasi seperti ini, sebagian orang atau kelompok yang sedang melakukan berbagai upaya politik seperti menghasut (ingratiation), mencari muka di hadapan pihak lain atau mempromosikan diri sendiri (self promotion) dengan melakukan tindakan yang jelas-jelas kelihatan maupun perilaku yang sangat halus sehingga pihak lain kurang menyadarinya. Orang-orang yang berada di luar dari pihak yang sedang melakukan upaya politik tersebut, secara sadar maupun tidak, lambat-laun akan merasakan pengaruh perilaku berpolitik mereka seperti rasa cemas, tegang, tertekan (stress). Bila kondisi ini berlarut-larut tanpa ada penyelesaian, pada akhirnya akan dapat mengakibatkan terjadinya aggressive behavior (perilaku agresif) karyawan (Vigoda, 2002).

Mengenai perilaku agresif, penelitian tentang hubungannya dengan politik organisasional juga telah banyak dilakukan. Perilaku agresif merupakan bentuk perilaku langsung untuk mencapai tujuan dalam suasana yang tidak menyenang$\mathrm{kan} /$ merugikan atau menghina pihak lain dengan motivasi untuk menunda perbaikan (Baron, 1997). Berkowitz (1993) dalam Vigoda, 2002 menyatakan bahwa perilaku agresif sebagai format perilaku yang ditujukan untuk melukai seseorang secara fisik dan psikis. Anderson dan Person (1999) mendefinisikan agresif sebagai perilaku menyimpang dengan niat dan kesungguhan untuk merugikan/melukai. Ada perbedaan batasan dengan yang lain seperti kekerasan, perilaku menyimpang, perilaku anti sosial dan perbuatan yang tidak berbudi. Menurut Anderson dan Person (1999), hasil studi mereka ditemukan bahwa sebagian dari perilaku agresif terjadi di tempat kerja, dapat berupa perilaku non verbal, pasif, tak langsung dan lebih tertutup. Dalam konteks ini, pihak lain yang terkena dampak perilaku agresif memang tidak merasakan secara langsung, tetapi cepat atau lambat pengaruhnya akan dirasakan oleh obyek, seperti merasa tidak nyaman, takut, stres, tertekan dan perasaan lain yang tidak menyenangkan dalam bekerja. Menurut Gilmore, Ferris, Dulebohn, dan Harrell-Cook, 1996 (dalam Vigoda, 2002) politik organisasional memiliki konsekuensi negatif termasuk di dalamnya adalah menyebabkan konflik dan ketidakharmonisan, yang dipandang darurat ketika individu dan/atau kelompok mencoba menyelesaikan permasalahan.

Dalam analisisnya, Gilmore et al., (1996) menggunakan terminology "hostile environment" atau lingkungan permusuhan yang menunjukkan bahwa adanya atmosfir tentang politik organisasional telah diciptakan. Dengan demikian, jika politik meningkatkan konflik antar individu dan kelompok seperti menciptakan suatu ruang kerja yang berhawa permusuhan, maka perilaku karyawan akan cenderung lebih 
menyukai untuk mempengaruhi dengan banyak cara, serta adanya kemungkinan mencapai titik ekstrim sebagai perilaku agresif secara verbal atau fisik.

Politik organisasional telah menjadi topik yang diminati untuk diteliti karena adanya tantangan potensial yang mempengaruhi efisiensi dan keefektifan organisasi. Karyawan yang mempersepsikan bahwa politik organisasional telah bersikap curang terhadap mereka sehingga mereka kehilangan kesempatan yang dimiliki, maka mereka cenderung menunjukkan reaksi negatif seperti ketidakpuasan, kecemasan, kelesuan, stres, dan turnover (Kacmar, Bozeman, Carlson, \& Anthony, 1999 dalam Vigoda, 2002).

Berkaitan dengan hasil studi-studi terdahulu yang cenderung menunjukan bahwa keduanya berbeda, studi ini menggunakan hasil tersebut sebagai dasar untuk menguji apakah politik dapat menjelaskan varians inkremental dalam variabel dependen melebihi yang dijelaskan dukungan, atau sebaliknya, bahwa dukungan menjelaskan varian inkremental melebihi politik.

Berbeda dengan penelitian terdahulu (Cropanzano, et al., 1997 dan Vigoda, 2002) penelitian ini mengambil sampel perawat di 2 rumah sakit di Daerah Istimewa Yogyakarta.

Penelitian Cropanzano et al. (1997) mengambil sampel 69 karyawan dari organisasi manufaktur yang berlokasi di Southwest United States yang terdiri dari 59 karyawan lini bagian administrasi, 10 supervisor, dan 6 lainnya di luar selain supervisor dan karyawan lini. 60\% diantaranya adalah karyawan wanita. Hasil studi Cropanzano et al. (1997) menemukan bahwa politik dan dukungan organisasional berhubungan dengan sikap kerja dan job distress. Dari hasil studi Cropanzano et al. (1997) juga ditemukan bahwa work stress (job tention, somatic tention, general fatigue dan burnout) berhubungan negatif dengan dukungan organisasional, tetapi berhubungan positif dengan politik organisasional.

Pada penelitian Vigoda (2002), sampel diambil dari tiga sektor, yaitu sektor swasta, sektor publik dan yayasan di Israel sejumlah 541 karyawan dengan bidang yang berbeda, seperti pelayanan pelanggan, jasa finansial, administrasi, manufaktur, pengembangan dan jasa internal lainnya. Hasil studi Vigoda (2002) menemukan bahwa politik organisasional berhubungan positif dengan stres kerja dan perilaku agresif. Ketiga penelitian terdahulu tersebut mengambil sampel pria dan wanita.

Di setiap perusahaan atau instansi manapun, masing-masing karyawan dituntut melakukan tugas secara optimal untuk menghasilkan yang terbaik bagi organisasi. Hal ini juga berlaku pada rumah sakit. Setiap perawat diwajibkan memberi pelayanan sebaik-baiknya kepada pasien. Di organisasi manapun tidak terkecuali rumah sakit, sering terjadi seseorang yang ingin memiliki wewenang dan kekuasaan menggunakan berbagai upaya bersifat politik agar memperoleh dukungan dari pihak lain dan tercapai kepentingan pribadinya. Menurut Kacmar dan Ferris (1992), persepsi tentang politik organisasional dipengaruhi oleh organisasi (seperti tingkatan hierarki, rentang pengendalian), lingkungan kerja (seperti otonomi kerja, variasi kerja, umpan balik, kesempatan untuk maju, interaksi dengan pihak lain 
dalam organisasi), dan pengaruh personal (usia, jenis kelamin, pengendalian diri sendiri).

\section{KAJIAN LITERATUR DAN HIPOTESIS}

\section{Politik Organisasional}

Politik tidak dapat sama sekali dihindari dan merupakan realita kehidupan organisasional, karena dalam banyak organisasi pertimbangan politik hampir selalu menjadi bagian dalam proses evaluasi, dibanding pertimbangan rasional (Longencker, Sims, \& Gioia, 1987). Politik organisasi telah didefinisikan dalam berbagai cara seperti Pfeffer (1981); pada Randall et al., (1999) yang menyatakan bahwa politik organisasi adalah "studi mengenai penerapan power". Karena power adalah salah satu hal penting dan selalu ada dalam organisasi, maka definisi ini meliputi seluruh proses yang terjadi secara nyata dalam work setting. Drory dan Romm (1990); pada Greenberg \& baron, 1997) menyatakan bahwa politik organisaional merupakan tindakan yang tidak secara formal dibuktikan dalam organisasi, dilakukan dalam mempengaruhi orang lain untuk mencapai tujuan perseorangan.

Para peneliti dan teoritisi telah menguji berbagai aspek tentang perilaku berpolitik dan persepsi tentang politik organisasional dengan perbedaan yang tidak jelas diantara keduanya. Ketika keduanya bersifat implisit, diasumsikan bahwa dua konstruk itu saling berhubungan, tetapi di sisi lain, pandangan terhadap kedua konstruk tersebut sebagai dua hal yang berbeda dan konstruk yang terpisah. Dalam bidang riset, politik organisasional dikonstrukkan sebagai persepsi, seperti yang dikutip oleh Ferris dan Kacmar (1992) dari berbagai studi, misalnya Gandz dan Murray (1980) yang menyatakan bahwa politik organisasional merupakan suatu pengalaman subyektif dan oleh karenanya ia akan menetap di pikiran. Persepsi dapat menyebabkan stres seperti yang dinyatakan model fit Michigan person environment (P-E) dari Caplan et al. (1975; pada Lansbergis \& Vivon-Vaughan, 1995), yang memasukkan persepsi sebagai salah satu stressor situasional. Mengacu pada Ferris, Russ, dan Fandt (1989; pada Kacmar et al., 1999) dalam model Perception Of Organizational Politics (POP). POP di pengaruhi oleh faktor-faktor organisasional (sentralisasi, formalisasi, jenjang hirarki, rentang pengendalian) pekerjaan/kerja (interaksi dengan pekerja lain, kesempatan berkembang, umpan balik, otonomi pekerjaan, variasi ketrampilan), dan perseorangan (usia, gender, machiavellianism, dan self-monitoring); yang akan mempengaruhi individual dan hasil organisasional seperti intensi untuk keluar, absen, kecemasan kerja, keterlibatan kerja, dan kepuasan kerja.

Persepsi tentang politik organisasional melibatkan di dalamnya mengenai evaluasi subyektif individu dalam mengamati situasi atau perilaku sebagai politik. Secara lebih khusus, persepsi tentang politik organisasional adalah interpretasi subyektif dari luasnya lingkungan kerja yang dikarakteristikkan oleh hubungan karyawan dengan supervisor yang diikat dalam perilaku berpolitik atau oleh kebijakan 
organisasional yang mendorong perilaku (Cook, G. H., Ferris, G. R., \& Dulebohn, J. H., 1999).

\section{Stres Kerja}

\section{Pengertian stress kerja}

Cooper (dalam Landsbergis, P A, \& Vivona - Vaughan, E) berpendapat bahwa stres merupakan suatu tekanan yang meletakkan faktor psikologis dan fisik di belakang rentang stabilitasnya yang menimbulkan ketegangan di dalam diri individu. Sedangkan Fisher, et al. (1990) mendefinisikan stress sebagai tanggapan, baik fisik maupun psikis, terhadap stressor. Stressor merupakan suatu kejadian yang menuntut/meminta suatu tindakan dari seorang individu. Dengan demikian menurut Fisher dan peneliti lainnya, stres tidak selalu merupakan fenomena yang merusak/merugikan karena dalam kenyataannya, sejumlah stres merupakan suatu hal penting dan proses yang mungkin perlu dilalui seseorang dalam rangka mencapai tujuan.

Definisi lain dikemukakan oleh Krantz (Miner, 1992) bahwa stres mengacu pada suatu keadaan internal dari seorang individu yang mempersepsikan adanya ancaman-ancaman atau tantangan-tantangan terhadap kondisi kesehatan fisik dan atau mental. Dalam pengertian stres di sini, menekankan suatu persepsi seseorang dan evaluasi dari rangsangan yang secara potensial membahayakan, serta mempertimbangkan persepsi dari tantangan/ancaman sebagai akibat dari perbandingan antara tuntutan yang dihadapi pada diri seorang individu dengan kemampuan seorang individu untuk mengatasi/memenuhi tuntutan tersebut. Suatu persepsi yang tidak seimbang pada mekanisme ini akan menimbulkan respon stress baik secara psikologis ataupun perilaku.

Bila digunakan untuk menggambarkan perasaan subyektif, stres merupakan persamaan dari ketegangan, kecemasan, kekhawatiran atau ketakutan. Ketika dlpandang dari sisi positifnya, stress dipandang 'baik' hanya karena berhubungan dengan hasil akhirnya, yaitu kesuksesan yang dicapai. Jadi, dalam percakapan sehari-hari, stress berarti sumber atau penyebab dari sesuatu yang tidak menyenangkan atau perasaan yang tidak menyenangkan itu sendiri, yang dikenal sebagai distress (Organ, 1979).

Berbagai studi menyebutkan bahwa ada kemungkinan perilaku politik karyawan dapat meyebabkan berbagai stress di tempat kerjanya (e. g., Gilmore, Feris, Dulebohn, \& Harrell-Cook, 1996; Ferris et al., 1996; Jex \& Beehr, 1991; Matteson \& Ivancevich, 1987 pada Vigoda, 2002). Studi-studi tersebut mengukur stress dalam beragam cara, namun semuanya berbasis pada kerja klasik "Selye's classic work" (1975). Selye memandang stres sebagai reaksi organisme terhadap siatuasi yang penuh tekanan dalam beragam kejadian, yang bisa menyangkut psikologis atau perilaku. Menurut Beehr, 1990 (pada Vigoda, 2002), stres didefinisikan sebagai bermacam-macam bentuk dari tempat kerja yang menyebabkan seorang karyawan mengalami rasa tidak senang. Cropanzano et al. (1997) mengutip 
pernyataan Edwards (1992) yang memberi argumen bahwa stres adalah perasaan subyek bahwa pekerjaan yang harus dilakukan individu melampaui kemampuannya. Jelasnya, beberapa definisi tentang stres ini bersifat kontradiktif. Tetapi Vigoda (2002) memutuskan bahwa stres merupakan respon individu terhadap stressors (penyebab stres) yang berasal dari pekerjaan atau lingkungan, salah satunya adalah politik organisasional.

Penelitian ini menggunakan pendekatan respon, sesuai dengan hasil penelitian Cropanzano et al. (1997) yang menguji hubungan politik dan dukungan organisasional dengan work stress dan Vigoda (2002) yang menguji hubungan politik organisasional dengan job distress. Hal ini sama dengan definisi yang dikemukakan oleh Selye bahwa stres merupakan reaksi individu dihadapkan dengan pertanyaan apakah mereka memiliki cukup kekuatan untuk merespon tuntutan. Reaksinya bisa bervariasi, tergantung pada individu dan situasi yang dihadapi.

\section{Sumber stres}

Ada beberapa faktor yang member kontribusi stres dalam dunia kerja, yaitu faktor-faktor yang berkaitan dengan organisasi atau kerja dan faktor-faktor yang berhubungan dengan aspek-aspek lain dalam kehidupan individu.

1. Sumber stress organisasional

Kahn dan Byosiere (1992) dalam Cropanzano, et al., (1997) membagi sumber stress dalam kehidupan organisasi menjadi 2 kategori, yaitu sumber stress fisikal dan sumber stres psikososial. Sumber stress fisikal berkaitan dengan lingkungan fisik organisasi, seperti penerangan, kebisingan, getaran dan sebagainya. Sumber stress psikososial berkaitan dengan lingkungan sosial organisasi. Sumber stress yang termasuk dalam kategori ini antara lain iklim organisasional, gaya manajemen, disain jabatan dan konflik peran. Dalam penelitian ini, stres bersumber dari psikososial yakni adanya politik dan dukungan organisasional yang dipersepsikan.

2. Sumber stress ekstra-organisasional

Faktor-faktor dari luar organisasi dapat berpengaruh terhadap dunia kerja, karena individu dapat pula beraktivitas dengan lingkungan di luar tempat kerjanya. Ketika aktivitas di luar organisasi menimbulkan stres, dapat saja stres ini terbawa ketika bekerja (Greenberg \& Baron, 2000). Stressor ekstraorganisasional ini meliputi factor-faktor seperti hubungan keluarga, wilayah tempat tinggal dan factor-faktor ekonomis, perkawinan, dinamika perubahan angkatan kerja (Hendrix et al., 1985).

\section{Respon terhadap stres}

Kahn dan Byosiere (1992) membagi respon individu terhadap stress menjadi 3 kategori, yaitu respon fisiologikal, respon psikologikal, dan respon perilaku. Berbagai temuan penelitian mengenai dampak stress terhadap kesehatan fisik menunjukkan bahwa level stres yang tinggi senantiasa diiringi dengan masalah 
kesehatan badan diantaranya dalah tekanan darah tinggi, tingkat kolesterol tinggi, bahkan dapat menyebabkan sakit jantung, bisul-bisul, sakit tulang, gejala-gejala pada saluran pencernaan.

Respon psikologikal adalah respon yang berkaitan dengan pemikiran atau perasaan, baik yang berhubungan dengan pekerjaan maupun tidak. Misalnya kecemasan, burnout, depresi, ketidakpuasan terhadap pekerjaan mapun kehidupan di luar organisasi, kelelahan, tertekan. Respon perilaku adalah respon yang berkaitan dengan perubahan perilaku yaitu degradasi peran kerja itu sendiri (misalnya menurunnya performance), perilaku agresif ketika bekerja (mencuri, melukai oang lain baik secara verbal maupun non verbal, menyebarkan rumor dan sebagainya), degradasi terhadap peran kehidupan di luar organisasi (seperti pelecehan terhadap pasangan) dan perilau merusak diri (mengkonsumsi alkohol, penyalahgunaan obatobatan).

\section{Dampak stres di tempat kerja}

Bagi organisasi, stress yang dialami tenaga kerjanya dapat mengakibakan rendahnya produktivitas, tingginya tingkat absensi, tingginya turnover (perputaran tenaga kerja) (Ray \& Miller, 1994 dalam Vigoda, 2002). Dampak negatif ini bisa menjadi lebih buruk ketika hasil dari stress kronis berupa burnout. Burnout adalah sekumpulan gejala yang merupakan akibat dari kontak panjang dengan stressor (Greenberg \& Baron, 2000) yang ditandai dengan kelelahan fisik, sikap, dan Burnout mengandung 3 komponen, yaitu kelelahan (merasa hidupnya kosong, lelah dan tidak dapat lagi mengatasi permasalahan dalam pekerjaannnya), depersonalisasi (pengembangan sikap sinis terhadap karier dan kerja diri sendiri, merasa bahwa tidak satupun dari aktivitas-aktivitas yang dilakukannya yang bernilai atau berharga, berpikir bahwa orang lain juga menganggap dirinya seperti yang dipikirkannya) dan penurunan prestasi.

Hanya beberapa peneliti yang baru tertarik untuk meneliti hubungan perilaku politik dan job distress. Mereka menemukan bahwa politik organisasional dimungkinkan sebagai suatu penyebab stres di tempat kerja. Hubungan keduanya dijelaskan dan diuji secara empirik dalam berbagai studi mulai pertegahan tahun 1990, sebagai contoh, Ferris, Fink, Gilmore dan Kacmar (1994), Gilmore et al (1996), Ferris et. al (1996), Bozeman et. al (1996) dan Cropanzano et. al (1997). Gilmore et. al (1996) pada Vigoda (2002) menjelaskan bahwa politik organisasional sebagai salah satu sumber penyebab stres dan konflik di lingkungan pekerjaan yang secara potensial bersifat disfungsional baik terhadap individu maupun level organisasi.

\section{Perilaku Agresif (Aggressive behavior)}

Perilaku agresif digambarkan oleh Baron, R. A. (1977) pada Vigoda (2002) sebagai beberapa bentuk perilaku langsung yang mengarah pada tujuan dalam hal yang merugikan atau melukai pihak lain dengan motivasi untuk menghindari dari berbagai perlakuan. Persamaannya dengan Berkowitz (1993) pada Vigoda, (2002) 
perilaku agresif sebagai sejumlah perilaku yang mengarah pada melukai seseorang baik fisik maupun mental.

Hubungan antara perilaku agresif dengan politik organisasional oleh Gilmore et. al (1996) dalam Vigoda (2002) memakai terminology "hostile environment" yang merefers bahwa ada kemungkinan tercipta atmosfir politik organisasional, sehingga jika politik mengarah pada konflik antar individu atau kelompok akan menciptakan sebuah permusuhan di tempat kerja, perilaku karyawan akan berdampak terhadap pihak lain hingga bila mencapai titik ekstrim cenderung ke perilaku agresif baik secara verbal maupun fisik.

\section{Politik organisasional dengan stress kerja}

Banyak studi yang telah menemukan bahwa perilaku berpolitik karyawan dapat menimbulkan stress yang berkaitan dengan tempat kerja (Gilmore et al., 1996; Ferris et al., 1996; Jex \& beehr, 1991; Mateson \& Ivancevich, 1987; pada Vigoda, 2002). Gilmore et al. (1996) menemukan bahwa politik organisasional sebagai sebuah sumber stress dan konflik dalam lingkungan kerja yang berdampak pada hasil yang tidak bermanfaat. Penelitian Cropanzano, et al., 1997 dihasilkan bahwa politik organisasional berhubungan positif dengan job tention. Vigoda (2002) menemukan bahwa politik organisasional berhubungan positif dengan job anxiety, job stress dan job distress.

\section{HIPOTESIS}

H1: Politik organisasional berpengaruh positif terhadap stres kerja. Politik Organisasional dengan Perilaku Agresif

Vigoda (2002) menemukan bahwa ada hubungan positif antara politik organisasional dengan perilaku agresif di tempat kerja. Cordes, C. L., \& Dougherty, T. W. (1993) menyatakan ada empat kelompok yang merupakan konsekuensi dari stress kerja yaitu fisik dan emosional, interpersonal, sikap dan perilaku. Maslach \& Jackson (1981) dalam Vigoda (2001) menyebutkan beberapa gejala fisik dengan adanya stress kerja seperti sakit kepala, batuk yang berkepanjangan, sakit pinggang, gangguan dalam selera makan dan sebagainya. Yang lebih penting dalam studi Vigoda (2002), stress kerja dan burnout mempengaruhi perilaku individu secara nyata. Orang dengan tekanan tinggi dalam pekerjaannya akan mengalami stress yang tinggi pula, dan tindakannya mudah dipengaruhi, mudah khawatir, atau memperlihatkan toleransi yang rendah terhadap orang lain. Dalam kenyataannya, berbagai gejala tersebut menjadi tipe perilaku agresif. Gilmore et al. (1996) dalam Vigoda (2002) menyatakan jika politik menimbulkan konflik antar individu dan kelompok sehingga menciptakan suasana saling permusuhan, perilaku karyawan akan berdampak terhadap berbagai hal, pada saat titik ekstrim dapat mengarah ke perilaku agresif baik secara verbal atau fisik.

H2: Politik organisasional berpengaruh positif terhadap perilaku agresif. 
Efek mediasi dari variable stres keria dalam hubungan antara politik organisasional dengan perilaku agresif

Ketika politik organisasional yang dijalankan oleh pihak tertentu dalam organisasi cukup kuat dan cenderung memihak golongannya sendiri, maka dampak langsung yang dialami oleh karyawan lain adalah merasakan stres kerja. Stres kerja yang berkepanjangan tanpa ada penyelesaian dari pihak organisasi maupun individu yang bersangkutan, akan berdampak terhadap keinginan untuk melakukan perilaku agresif, diantaranya: melukai pihak lain dengan cara tertutup maupun terangterangan (Vigoda, 2002).

H3: Stres kerja memediasi hubungan antara politik organisasional dengan perilaku agresif.

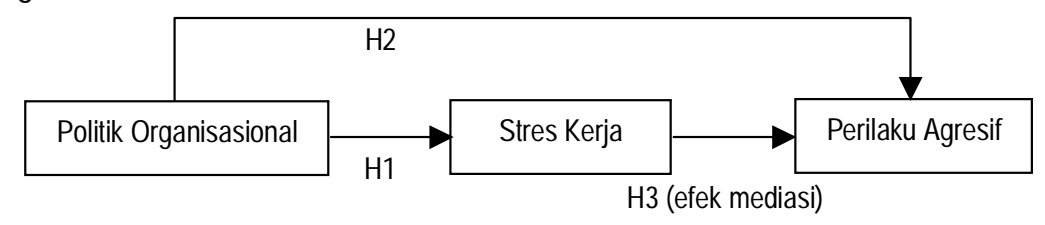

Gambar 1: Model Penelitian

\section{METODE PENELITIAN}

\section{Populasi dan Sampel}

Populasi penelitian ini adalah perawat di RS PKU Muhammadiyah (Pusat) dan perawat DKT di Yogyakarta. Sedangkan yang dijadikan sample adalah perawat bagian rawat inap. Kuesioner dibagikan kepada perawat bagian rawat inap di PKU Muhammadiyah sebanyak 43 , kembali sebanyak 40 , sedangkan perawat DKT dibagikan sebanyak sebanyak 50, kembali dan diisi lengkap sebanyak 46.

Pemilihan sampel dilakukan dengan cara judgment sampling. Penggunaan judgment sampling bertujuan agar sampel yang dipilih adalah mereka yang sesuai dengan karakteristik populasi dengan kriteria: perawat yang sudah menikah dan telah menjadi pegawai tetap. Alasannya mereka memiliki peran ganda yakni sebagai pegawai, sebagai suami/isteri dan sekaligus sebagai orang tua sehingga tingkat stresnya kemungkinan besar cukup tinggi karena ada tuntutan bekerja keras untuk memenuhi tuntutan dari peran itu.

\section{Pengukuran dan pengujian variable penelitian}

a. Politik organisasional diukur dengan menggunakan versi pendek dari Perceptions of Organizational Politic Scale (POPS) (Vigoda, 2002). Versi ini memuat 6 item dari 32 versi asli yang dikembangkan oleh Kacmar dan Ferris (1992). 
b. Stres kerja diukur dengan 4 item dan merifers dari tiga tipe tentions-stress factors: job-induced tention (JIT), somatic tention (ST) dan general fatigue and uneasiness (GFU) dari House dan Rizzo, 1972; pada Vigoda (2002).

c. Perilaku agresif diukur dengan 4 item (Berkowitz, 1993; pada Vigoda, 2002).

d. Variable kontrol yang dipakai meliputi: jenis kelamin, usia, dan lama kerja.

Variabel kontrol diikutkan berdasarkan adanya penemuan dalam studi terdahulu, misalnya: Vigoda (2002) menemukan bahwa politik organisasional berhubungan dengan stres kerja, kepuasan kerja dan komitmen organisasi. Disamping itu, usia berhubungan siknifikan dengan komitmen organisasi, stres kerja. Lamanya bekerja berhubungan siknifikan dengan politik organisasional, stres kerja, perilaku agresif dan komitmen organisasi. Stres kerja pada kaum wanita yang berperan ganda relatif lebih tinggi daripada pria.

\section{HASIL ANALISIS}

Data yang diperoleh dianalisis dengan dua pendekatan analisis regresi sederhana yang dipakai untuk menguji $\mathrm{H} 1$ dan $\mathrm{H} 2$, sedangkan $\mathrm{H} 3$ diuji menggunakan HRA (analisis regresi hirarkikal). Hasil pengujian hipotesis 1 dan 2 dapat dilihat pada table 1 dan table 2 .

Tabel 1: Hasil Pengujian Hipotesis 1

\begin{tabular}{|c|c|c|c|c|c|}
\hline $\begin{array}{c}\text { Variabel } \\
\text { Independen }\end{array}$ & B & $\mathrm{T}$ & Sig. & $\mathrm{R}^{2}$ & $\mathrm{~F}$ \\
\hline \hline $\begin{array}{c}\text { Politik } \\
\text { Organisasional }\end{array}$ & 0,091 & 0,857 & 0,039 & 0,009 & 0,735 \\
\hline
\end{tabular}

Dependen Variabel: Stres Kerja

Berdasarkan analisis regresi sederhana (Table 1 ) untuk menguji hipotesis 1 menunjukkan bahwa hipotesis 1 didukung $(B=0,091 ; t=0,394 ; p<0,05)$. Artinya politik organisasi berpengaruh positif dan signifikan terhadap stress kerja. Bila suhu politik dalam organisasi meningkat, maka tingkat stress kerja perawat juga meningkat. Hasil ini mendukung penelitian Vigoda (2002) bahwa politik organisasional berpengaruh langsung terhadap stress kerja karyawan.

Tabel 2: Hasil Pengujian Hipotesis 2

\begin{tabular}{|c|c|c|c|c|c|}
\hline $\begin{array}{c}\text { Variabel } \\
\text { Independen }\end{array}$ & $\mathrm{B}$ & $\mathrm{T}$ & $\mathrm{Sig}$. & $\mathrm{R}^{2}$ & $\mathrm{~F}$ \\
\hline $\begin{array}{c}\text { Politik } \\
\text { Organisasional }\end{array}$ & 0,110 & 0,982 & 0,33 & 0,011 & 0,964 \\
\hline
\end{tabular}

Dependen Variabel: Perilaku Agresif

Berdasarkan analisis regresi sederhana (Tabel 2) untuk menguji hipotesis 2 menunjukkan bahwa hipotesis 2 tidak didukung ( $B=0,110 ; t=0,982 ; p>0,05)$. 
Artinya politik organisasi tidak berpengaruh signifikan terhadap perilaku agresif. Hasil ini mendukung penelitian Vigoda, (2002) yang menyatakan bahwa politik organisasional tidak berpengaruh langsung terhadap perilaku agresif.

Tabel 3: Hasil Pengujian Analisis Regresi Hirarkikal (HRA)

\begin{tabular}{|l|c|c|c|c|}
\hline \multicolumn{1}{|c|}{ Variabel } & \multicolumn{4}{|c|}{ Perilaku Agresif } \\
\hline \hline Tahap 1 & B & T & $\mathbf{R}^{\mathbf{2}}$ & $\mathbf{R}^{\mathbf{2}}$ \\
Jenis Kelamin & $-0,065^{\star}$ & $-0,266$ & 0,018 & 0 \\
Usia & $-0,014$ & $-0,769$ & & \\
Lama Kerja & 0,024 & 1,083 & & \\
$\quad$ Tahap 2 & $-0,083$ & $-0,339$ & 0,031 & 0,013 \\
Jenis Kelamin & $-0,015$ & $-0,827$ & & \\
Usia & $-0,025$ & 1,119 & & \\
Lama Kerja & $0,115^{*}$ & 1,013 & & \\
Politik Org. & & & \\
Tahap 3 & 0,075 & 0,374 & 0,372 & 0,341 \\
Jenis Kelamin & $-0,022$ & $-1,500$ & & \\
Usia & $0,037^{*}$ & 2,051 & & \\
Lama Kerja & 0,047 & 0,512 & & \\
Politik Org. & $0,633^{\star}$ & 6,556 & & \\
Stres Kerja & & & & \\
Tingkat signifikansi: * & & & & \\
p<0,05 & & &
\end{tabular}

Tabel 3 menunjukkan hasil pengujian hipotesis 3 menggunakan analisis regresi hirarkikal yang terdiri dari 3 tahap, menyatakan bahwa stres kerja memberikan efek mediasi positif pada hubungan antara politik organisasional dengan perilaku agresif dengan peningkatan varians sebesar 34\%. Temuan ini sesuai dengan hasil yang diperoleh Vigoda (2002). Secara lebih rinci hasil masing-masing tahap adalah: tahap 1, menunjukkan variable kontrol usia dan lama kerja secara signifikan tidak berpengaruh terhadap perilaku agresif sedangkan jenis kelamin secara signifikan berpengaruh terhadap perilaku agresif. Tahap 2, pada saat ditambahkan variable politik organisasional, menunjukkan bahwa politik organisasional secara positif dan signifikan berpengaruh terhadap perilaku agresif $(B=0,115$; $t=$ $1,013 ; \mathrm{p}<0,05)$. Sedangkan semua variable kontrol secara signifikan tidak berpengaruh terhadap perilaku agresif. Hasil pengujian tahap 3, dengan menambahkan variable stres kerja, menunjukkan bahwa jenis kelamin dan usia tidak berpengaruh terhadap perilaku agresif. Lama kerja secara positif dan signifikan berpengaruh terhadap perilaku agresif. Hal ini kemungkinan disebabkan semakin lama perawat bekerja di rumah sakit tersebut, timbul kejenuhan dalam diri mereka, sehingga bila tidak segera diantisipasi masalah ini oleh manajemen rumah sakit, karyawan cenderung melakukan perilaku agresif, misalnya dalam bentuk: membuat 
suasana kerja menjadi tidak nyaman dengan menyebarkan berita-berita buruk tentang manajemen rumah sakit, agar dengan cara itu mereka memperoleh perhatian. Politik organisasional secara signifikan dan positif tidak berpengaruh terhadap perilaku agresif $(B=0,047 ; t=0,512 ; p>0,05)$, sedangkan stres kerja secara signifikan dan positif berpengaruh terhadap perilaku agresif $(B=0,633 ; t=6,556$; $p<0,05)$. Dengan demikian hipotesis 3 yang menyatakan bahwa stres kerja memediasi hubungan antara politik organisasional dengan perilaku agresif didukung. Artinya, semakin tinggi suhu politik organisasional yang dilakukan oleh sekelompok tertentu dalam organisasi akan berpengaruh langsung terhadap stress kerja, dan berpengaruh tidak langsung terhadap perilaku agresif karyawan.

\section{IMPLIKASI PENELITIAN}

\section{Implikasi Akademis}

Stres kerja memberikan efek mediasi pada hubungan antara politik organisasional dengan perilaku agresif. Artinya pengaruh politik organisasional terhadap perilaku agresif tidak secara langsung terjadi, tetapi melalui stres kerja. Hasil ini konsisten dengan penemuan Vigoda (2002), dan akan lebih memperkuat pernyataan bahwa stress kerja merupakan variable pemediasi hubungan antara politik organisasional dengan perilaku agresif. Beberapa temuan dalam penelitian ini yang tidak sesuai dengan hasil penelitian sebelumnya, diduga ada pengaruh karakter responden (jender, usia, lama kerja) dan sector perusahaan yang diteliti, sehingga memang sulit untuk menggeneralisasi terhadap hasil penelitian ini.

\section{Implikasi Praktis}

Secara umum hasil penelitian ini dapat bermanfaat sebagai pertimbangan dalam mengelola karyawan terutama bila menghadapi sekelompok orang atau individu tertentu yang melakukan politik organisasional hanya untuk kepentingan mereka sendiri, sehingga karyawan yang ada di luar kelompok tersebut merasa kurang tenang dalam bekerja, yang berdampak stress kerja atas dirinya terutama ketika sekelompok pelaku politik organisasional tersebut mulai berusaha dengan terang-terangan memaksakan kehendaknya. Politik organisasional yang memang suatu fenomena yang pasti ditemui di hampir semua organisasi, sehingga pihak manajemen perlu memikirkan bagaimana mengelola dan mengarahkan politik organisasional yang dilakukan karyawan kepada hal yang positif, artinya dilakukan untuk kepentingan seluruh anggota organisasi, bukan untuk kepentingan kelompok tertentu. Di samping itu, manajemen perusahaan dapat belajar untuk mengelola stress kerja karyawannya sehingga tidak mengarah kepada perilaku agresif yang berdampak merugikan organisasi yang bersangkutan. 


\section{KETERBATASAN PENELITIAN DAN SARAN}

1. Perbedaan sector perusahaan yang dijadikan obyek penelitian ini (rumah sakit), sehingga dimungkinkan akan mempengaruhi jawaban. Akan lebih baik dalam penelitian yang akan dating mencoba menggunakan sector berbeda sehingga hasilnya akan lebih baik.

2. Responden hanya diambil dari 2 rumah sakit, sehingga penelitian yang akan datang sebaiknya menggunakan responden yang meliputi lebih dari 2 rumah sakit.

3. Data yang diperoleh bersifat self report, sehingga dimungkinkan terjadi commont method bias (Podsakoff, McKenxie and Podsakoff, N. P, 2003; dalam Sekaran 1992). Selain itu data yang diperoleh bersifat cross sectional, bukan time series, sehingga jawaban responden hanya terbatas pada jawaban saat ini, sedangkan untuk masa yang akan datang maupun masa sebelum penelitian tidak dapat digeneralisir dalam penelitian ini.

\section{DAFTAR PUSTAKA}

Cohen, A, \& Vigoda, E. (1999). Politics and the workplace. An empirical examination of the relationship between political behavior and work outcomes. Public Productivity \& management Review. 20 (3): 389 - 406.

Cook, G. H., Ferris, G. R., \& Dulebohn, J. H. (1999). Political behavior as moderators of the perceptions of organizational politics-work outcomes relationship. Journal of Organizational Behavior, 20: 1093-1105.

Cropanzano, R., Howes, J. C. Grandey, A. A., \& Toth, P., (1997). The relationship of organizational politics and support to work behaviors, attitudes, and stress. Journal of Organizational Behavior, 18: 159 - 180.

Dessler, G. 2000. Human Resource Management, 8 th edition. New Jersey: Prentice Hall.

Ferris, G. R \& Kacmar, K. M. (1992). Perceptions of organizational politics. Journal of Management, 18 (1): 93 - 116.

Ferris, G. R \& Kacmar, K. M. (1992). Perceptions of organizational politics. Journal of Management, 18 (1): 93 - 116.

Greenberg, J., \& Baron, R. A. (1997). Behavior in organizations: Understanding and managing the human side of work. New Jersey, USA: Prentice - Hall International, INC.

Harrel - Cook, G., Ferris, G. R., \& Dulebohn. J. H. (1999). Political Behaviors as moderators of the perceptions of organization politics - work outcomes relationship. Journal of Organization Behavior, 20: 1093 - 1105. 
Helmi, A. F., \& Ramdhani, N. (1994). Perilaku agresif dan depresif pada anak-anak di kawasan kumuh Ledok Ratmakan Yogyakarta. Fakultas Psikologi. UGM. Yogyakarta.

Hendrix, W. H., Ovalle, N. K., \& Troxler, R. G. (1985). Behavioral and physiological consequences of stress and its antecedent factors. Journal of Applied Psychology, 70 (1) : 188-201.

Jex, M., Beehr, T. A. \& Roberts, C. K. (1992). The meaning of occupational stress item to respondents. Journal of Applied Psychology, 77 (5): 623-628.

Johnston, M. W., Griffeth, R. W., Burton, S \& Carson, P. P. (1993). An exploratory investigation into the relationships between promotion and turner: A quasi experimental longitudinal study. Journal of Management, 19 (1): 33 - 49

Kacmar, K. M, Bozeman, D. P., Carlson, D. S., \& Anthony, W. P. (1999). An examination of the perception of organizational politics model: Replication and extension. Human Relation, 52 (3): $383-416$.

Kahn, R. L. \& Byosiere, P. (1992). Stress in organization. In M. D. Dunnete \& L. M. Hough (Eds). Handbook of Industrial and Organizational Psychology, 3 th Volume: 571-650. Palo Alto, CA: Consulting Psychologist Press.

Meyer, J. P., Allen, N. J., \& Smith, C. A. (1993). Commitment to organizations and occupations: Extension and test of a three - component conceptualization. Journal of applied psychology, 78 (4): 538 - 551.

Meyer, J. P., Allen, N. J. (1993). Organizational commitment: evidence of career stage effects? Journal of Business Research, 26: $49-61$.

Miner, Ganster, D. C., Fusilier, M. R., \& Mayes, B. T. (1992). Role of social support in the experience of stress at work. Journal of Applied Psychology, 71 (1): 102110.

Mobley, P., \& parkes, K. (1999). The effects of transition stress: relocation study. Journal of Organizational behavior, 20: 625-646.

Organ, D. W. (1979). The meaning of stress. Business Horizans, 22 (3): 32-40.

Randall, M. L., Cropanzano, R., Bormann, C. A., \& Birjulin, A. (1999). Organizational politics and organizational support as a predictor of work attitudes, job performance, and organizational Citizenship Behavior. Journal of Organizational Behavior, 20: 159 - 174.

Sekaran, U. (1992). Research Methods for Business: A Skill-Building Approach. Singapore, Singapore: John Wiley \& Sons. Inc.

Supratiknya, A. (1995). Mengenal Perilaku Abnormal. Kanisius. Yogyakarta. 
Vigoda, E. (2002). Stress-related aftermaths to workplace politics: the relationships among politics, job distress, and aggressive behavior in organizations. Journal of Organizational Behavior, 23: 571-591. 